\title{
E-waste Management In Indian Microscale Informal Sectors - An Environmental Perspective Towards Policy Regulation
}

\section{Dipsikha Dasgupta}

Jadavpur University

\section{Santanu Majumder}

University of Birmingham

Jishnu Adhikari

dSanborn, Head \& Associates, Inc.

Pinaki Ghosh

University of Kalyani

Diane Purchase

Middlesex University

Hemda Garelick

Middlesex University

Anupam Debsarkar

Jadavpur University

Debashis Chatterjee ( $\sim$ dbchat2001@rediffmail.com )

University of Kalyani

\section{Research Article}

Keywords: E-waste, Informal Sectors, Hazardous metal(loid)s, Environmental Pollution, Policy Implications.

Posted Date: January 12th, 2022

DOI: https://doi.org/10.21203/rs.3.rs-1089035/v1

License: (c) (i) This work is licensed under a Creative Commons Attribution 4.0 International License.

Read Full License 


\section{Abstract}

Inappropriate e-waste processing in the informal sector is a serious issue in developing countries. Field investigations in microscale informal recycling sites have been performed to study the impact of hazardous metal(loid)s (released from e-waste dismantling) on the environment (water and soil). Eight hazardous metal(loid)s ( $\mathrm{Pb}, \mathrm{Cd}, \mathrm{Cu}, \mathrm{Zn}, \mathrm{As}, \mathrm{Hg}, \mathrm{Ni}$ and $\mathrm{Cr}$ ) were found at elevated levels in the monitored water and soil samples (Sangrampur, West Bengal) as a consequence of widespread informal e-waste handling and primitive processing. $\mathrm{Pd}, \mathrm{Cu}$ and As were found in high concentrations in water samples $\left(1.62,1.40,0.03 \mathrm{mgL}^{-1}\right.$ respectively). Significant levels of $\mathrm{Cu}, \mathrm{Pd}$ and $\mathrm{Cd}$ were detected in collected soil samples, both topsoil (Cu up to $2328.60 \pm 217.60, \mathrm{~Pb}$ up to $342.90 \pm 32.36$ and $\mathrm{Cd} 18.34 \pm 3.81 \mathrm{mgkg}^{-1}$ ) and subsurface soil $\left(2491.40 \pm 276.20,1853.33 \pm 144.79,25.90 \pm 9.53 \mathrm{mgkg}^{-1}\right)$, compared to the levels of $\mathrm{Zn}, \mathrm{As}, \mathrm{Hg}, \mathrm{Ni}$ and $\mathrm{Cr}$. The results of seasonal variation indicated that higher levels of these hazardous meta(loids) were detected in the pre-monsoon (Nov - May) season than the rest of the year, as open dumping/burning of e-waste were practiced commonly and frequently in the monitored sites. The results highlighted that the composition and the handling of e-waste were important factors affecting the metal(loid) concentrations. E-waste policy and legislation have great influence on the handling and disposal procedures. A novel improved e-waste management practice has been proposed to encourage eco-friendly and safe e-waste disposal. It is recommended that regulatory agencies and manufacturers should create a road map to convince the informal sector to develop a systematic approach towards a more standardized formal e-waste management practices at the microscale field level.

\section{Introduction}

The disposal of electrical and electronic equipment (EEE) is an increasing global challenge due to the rapid obsolescence of technology, shorter lifespan of devices, inappropriate recycling and reuse of ewaste in the informal sectors (Balde et al. 2015; Awasthi et al. 2016; Dasgupta et al. 2017). Globally, the generation of e-waste was 42 MT in 2014 occupying about $5 \%$ of the total generated municipal solid waste and, by 2017 increased up to 72 MT (Ongondo et al. 2011; Ikhlayel 2016). The growth of e-waste has been exponentially expanding especially over the last two decades (Dasgupta et al. 2014; Purchase et al. 2020). The e-waste generation growth rate (both globally and regionally) clearly indicates that the existing management protocol of e-waste is complex and multifaceted that needs serious policy attention.

In Europe, the recently (2018) legislated streamlining activities (building systems to reuse and recycle old EEEs) are focused on ensuring a better mechanism for handling and disposal of the e-waste (Table 1) (Purchase et al. 2020). Poorly working and easily disposable EEE items are the principal source of ewaste at the end of their lifespan (Ongondo et al. 2011). These items include personal computers, laptops, televisions, mobile phones, and household gadgets - most often discarded by the users. Consequently, the per capita e-waste generation is increasing, and the generation of e-waste leads to an increase in the handling and disposal problems with high ecological impact (Dasgupta et al. 2014). It has been reported that per capita generation of e-waste is the highest in Norway ( $28.5 \mathrm{~kg})$. US and Canada 
produce $20 \mathrm{~kg}$ of e-waste (per capita) whereas countries in Latin America contribute $10 \%$ of generated ewaste worldwide (Purchase et al. 2020). In Asia, China is the highest e-waste generator (total) whereas the US is the annual highest global e-waste producer (10 MT, 2017) (Dwivedy and Mittal 2010; Wath et al. 2010; Wath et al. 2011). However, Asian countries face an increased and complex challenges due to the rising use of electronic appliances and their disposal rate.

Developed countries have strict laws and protocols to tackle huge volume of e-waste, whereas the scenario is entirely different in the developing countries (Ongondo et al. 2011; Garlapati 2016). In developing countries, laws are implemented in a very relaxed manner and most of the generated e-waste is handled in the informal sector. The informal sector has a lucrative business model and is mostly operated from the outskirts of megacities (Secretariat Report 2007; Nandi 2010; Secretariat Report 2011). A large section of the population in the developing countries buys second-hand products from secondhand markets (SHM) due to economic constraint (Dasgupta et al. 2017). The products from the SHM, are used by the consumers after necessary refurbishment. These SHMs then contribute to the mushrooming growth of e- wastes from the informal sector. They handle approximately $90 \%$ of the total generated ewaste in developing countries and are vital to the livelihood of the engaged human workforce (Young 2004; Satyamurty 2006; Toxic Link 2007).

Amongst the developing countries, India is a renowned 'hot spot' of e-waste generation as well as a dumping destination (Purchase 2020). A huge quantity of e-waste was generated (15MT) in 2015 with an annual growth of 25\% (Ongondo F 2011). In India, ten techno-commercial cities contribute to nearly $70 \%$ of total e-waste generated (Toxic Link India, 2007,Rajya Sabha Secretariat, New Delhi, 2011]. The major primary sources of e-waste in India (70\%) are governmental (15\%), public (23\%) and private (32\%) sectors followed by household contributors (15\%) (Satyamurty 2006; Secretariat Report 2010). E-waste generation is complex because reuse, storage and recycling are always practiced before final landfilling (Dwivedy and Mittal 2010). Among these, the reuse practice is principally dependent on the market demand of the product (reselling). The large quantities of e-waste that are eventually dumped at the recycling sites have the potential to release/emit substantial amount of contaminants/pollutants in soil and water environment (The Hindu 2014; Dasgupta et al. 2015).

E-waste recycling/recovery operations and open burning activities release several hazardous substances. These are mostly toxic metal(loid)s and organic compounds (e.g., flame retardants) that are detrimental to environment and public health (Dasgupta et al. 2015; Guha Thakurata 2015). Studies suggest that recyclers/handlers/waste workers (primarily children and women) are largely affected by the exposure of inorganic/organic substances derived from e-waste processing in India, including Kolkata and the surrounding areas (Chen et al. 2011; Guha Thakurata 2015). Existing policies are made for macroscale management of e-waste (Rigoldi et al. 2018). However, inappropriate e-waste handling leads to their unrestrained disposal which may cause serious impact on water, soil and human health (Dasgupta et al. 2015). This needs future policy amendments to bridge up knowledge and policy gaps mainly at local microscale level. The 'microscale' e-waste processing is done by small group of people 
(10-20 heads) and mostly dominated by women and children. The operation is largely dependent on ewaste supply chain amounting up to 3 MT/year (Dasgupta et al. 2014, 2017).

This study focuses on hazardous metal(loid) pollution from microscale informal sector e-waste processing sites in rural India, which is underexplored in Indian sub-continent. A comprehensive field scale study has been conducted to demonstrate the enrichment of hazardous metal(loid)s in water and soil environment and their seasonal variation - to establish a relation between toxic metal(loid) mobilization and microscale e-waste processing. Moreover, the study also critically examines the link between microscale informal trade chain practices and their consequence on final disposal, its ecological impact and management policies. Finally, an appropriate management skill model has been developed to resolve the challenges in entire south-east Asia to regularize e-waste processing in rural microscale informal sectors.

\section{Study Area}

The study area, near Sangrampur $\left(22^{0} 12^{\prime} 4.7^{\prime \prime}-22^{0} 14^{\prime} 8.0^{\prime \prime} \mathrm{N}\right.$ and $88^{0} 18^{\prime} 58^{\prime \prime}-88^{0} 22^{\prime} 57^{\prime \prime} \mathrm{E}$, South 24 Parganas, West Bengal), is $75 \mathrm{~km}$ away from Kolkata Metropolis and fall within the "tropical wet and dry' category (Dasgupta et al. 2015, 2017). The daily maximum temperature hovers around the $30-40{ }^{\circ} \mathrm{C}$ in summer and winter $10-20^{\circ} \mathrm{C}$. The average annual rainfall is about $1750 \mathrm{~mm}$ (Dasgupta et al. 2015, 2017). Four different sites have been selected for the study, namely - Teckpanja (Site 1), Bankipur (Site 2), Talpadmer Hat (Site 3) and Jhapberia (Site 4). Nishapur (Site 5) was selected as the control site having no history of e-waste handling. The field visit revealed that the informal recycling activities are being practiced in site 1, 2, 3, and 4 for nearly three decades (1994) (Fig. 1). The soil texture of all the sites (area up to 524 sq. ft) appeared to be burnt, tarnish and completely black in colour (Fig. 2a). During field expedition, these e-waste burning sites were found to be low and flat, rich in fresh organic matter due to decomposition of animal wastes and were often used for the cattle grazing.

E-waste items are often refurbished, and useable electronic items are sold to the SHMs/scrap dealers which are commonly regulated by trade chain practices (Fig. 3). The recovered components are sold for recycling purposes along with local market. Several kinds of e-waste are processed in those monitored recycling sites. The major items are Printed Circuit Boards (PCB), Power Cables, Cathode Ray Tubes (CRT), Lead Containing Solders, Plastic Housing, Nickel-Cadmium Batteries (Fig. 2b). In the dismantling operation, the equipment used is mostly primitive in nature and rudimentary in type (hammer, chisels, hand driven driller). However, the methods of operation are highly non-standardized being labour intensive and without any energy sources. Dismantling (e.g., PCB) is done by hammering to recover metals and the dismantled e-items are regularly washed into the nearby ponds. Several plastic-coated eitems are open-burned to recover the metals from inside. The burning activity takes place 2-4 times a week (Dasgupta et al. 2015, 2017).

\section{Methods And Materials}




\subsection{Sample collection and preparation}

Soil

The sampling campaign (composite and representative soil sampling) have been conducted for premonsoon (Pre M, April'2017) and post-monsoon (Post M, October'2017) seasons. Vertical depth-wise [015 , and $15-45 \mathrm{~cm}$ below ground level (bgl)] composite samples were collected from the monitored four sites. Collected samples were air dried, and manually homogenized. Each air-dried sample was then transferred to a stainless-steel sieve ( $<2 \mathrm{~mm})$, which was then covered with a steel lid and shaken manually. The sieved samples were stored and transported to the laboratory on the day of sampling and kept at $4 \pm 1^{\circ} \mathrm{C}$.

\section{Water}

Water samples (grab) were collected from four different ponds (at $20 \mathrm{~cm}$ below the surface, Fig. 4), each from one study site, located in the vicinity of e-waste open-burning sites (2-5 m) during Pre $M$ and Post M season. Samples were collected in pre-acid cleaned PET bottles $(100 \mathrm{~mL})$, they were acidified $(2 \% \mathrm{v} / \mathrm{v})$ with $\mathrm{HNO}_{3}$ (ultrapure, Merck) and stored in ice-box $\left(4 \pm 1^{\circ} \mathrm{C}\right)$. Then they are transported to the laboratory on the day of sampling and kept at $4 \pm 1^{\circ} \mathrm{C}$ till the analysis.

\subsection{Analysis of metals}

Concentrations of $\mathrm{Pb}, \mathrm{Cd}, \mathrm{Cu}, \mathrm{Zn}, \mathrm{Ni}$ and $\mathrm{As}$ in the soil and water samples were determined. For hazardous metal screening, soil samples were extracted by the method used in Fujimori et al. (2012). In short, collected soil samples $(1 \mathrm{~g})$ were pre-digested overnight in conical flask with equal volumes $(3 \mathrm{~mL})$ of different mixture of acids $\left(\mathrm{HNO}_{3} 60 \%+\mathrm{HCl} 35 \%\right.$ ultrapure, Merck) with deionized water $(25 \mathrm{~mL})$. The overnight acid-soaked samples in a conical flask covered with a watch glass are then heated on a hotplate (up to $125 \pm 5^{\circ} \mathrm{C}$ ) for $2 \mathrm{~h}$ and the watch glass was removed. The samples were further heated for nearly 10-15 mins until the total volume was reduced to $15 \mathrm{~mL}$ and cooled down to room temperature. They were filtered $(0.45 \mu$, Sartorious, Germany) and the volumes were made up to $50 \mathrm{~mL}$ in a flask. The water samples were filtered $(0.25 \mu$, Sartorious, Germany) to remove any tiny, suspended particulates. The filtered samples $\left(50 \mathrm{~mL}\right.$ ) were then acidified (conc. $\mathrm{HNO}_{3} 2.5 \mathrm{~mL}$, ultrapure, Merck) and digested on a hotplate. Digestion continued until a clear solution obtained. The solutions were cooled down to room temperature and then transferred to a volumetric flask and made up to $100 \mathrm{ml}$ (Fujimori et al. 2012; Maris et al. 2015; Vazquez et al. 2017). The acidified water samples were filtered (0.45, Sartorius, Germany) before elemental analysis was carried out.

The hazardous metals in the acid extracted soil samples and water samples were measured by atomic absorption (Varian, AA 240, $\mathrm{Hg}$ in cold vapour, As in hydride generation mode) as per a standard methods (Baird et al. 2017). Twenty percent of the samples were selected randomly to test the precision of the 
analysis (>97\%, p < 0.01). Certified Reference Materials (NIST SRM 2709a, SEM 1643e) were used to maintain the accuracy of the analysis. The statistical analysis was performed using SPSS 7 (Softonic).

\section{Results And Discussion}

\subsection{Pond Water Contamination}

The levels of hazardous metals in the monitored pond water samples are summarized (Table 2). Results indicate that $\mathrm{Cd}$ levels are relatively high, almost in all the sites with regards to both the national (BIS 2012) and WHO guideline values (WHO 2008), during both the pre- and post-monsoon seasons. Similarly, $\mathrm{Pb}$ and As have shown similar trends. The monitored pond water in the vicinity of e-waste opens burning sites appeared to be affected by hazardous influence from certain toxic metals. In particular, $\mathrm{Cd}, \mathrm{Pb}$ and As seemed to have leached out from burnt e-waste residues into the pond waters.

Spatial and temporal variations of hazardous metals across the study sites are also observed. The levels (at Site 2 and 3 ) of $\mathrm{Cd}, \mathrm{Cr}$ and $\mathrm{Pb}$ for both seasons are higher than the permissible limit for safe water (National as well as WHO standards) which is not true for other monitored sites. Nevertheless, levels of $\mathrm{Cd}$ and $\mathrm{Pb}$, are higher than the WHO permissible limit for all monitored samples (WHO 2008). The study indicates the presence of hazardous metals in all monitored pond waters, often used for drinking purposes, located in the vicinity of the open burning sites. However, the levels are varied, the metal(loids) raised serious environmental concern when exceeded the National drinking water standard as well as the WHO guideline values recommended for human health protection (WHO 2008; BIS 2012). Cd, Cr and Pb are often higher in the pond water, notably at Site 3.

This possibly indicates the regular use of pond water to wash the burnt e-waste residues, primarily from PCB, smart card chips, CRT containing CdS, photovoltaic panels, capacitors and batteries - which are commonly found in the disposed e-waste (Fig. 4). Similarly, $\mathrm{Hg}$ is probably leaching out from LCDs and/or batteries that are widespread and regularly burnt (Schlummer 2007; Dimitrakakis et al. 2009; Erickson and Kaley 2011). Seasonal variation is always an important issue with regard to the monitored pond water. A distinct feature is the higher levels of all the hazardous metals in pre-monsoon season compared to post-monsoon. The post-monsoon levels are mostly within the safer limits. The levels of $\mathrm{Pb}$ and As (Site 1), Cd (Site 2), Cd, Cr, Pb (Site 3) have also been found above the permissible limit of drinking water (WHO 2008), even in few cases National drinking water standard (BIS 2012).

The seasonal variation can be explained by the monsoonal dilution effect, thereby resulting in lower concentrations of toxic metals, post-monsoon. The often-found higher concentrations of $\mathrm{Cd}, \mathrm{Cr}, \mathrm{Pb}$ and As reflect the frequent use of pond water to wash the burnt residues, thereby metals are released to aqueous environment. This is due to recovery of hazardous metals ( $\mathrm{Cd}, \mathrm{Pb}, \mathrm{Zn}, \mathrm{Cr}, \mathrm{As}, \mathrm{Hg}$ ) that are usually done by acid stripping with strong oxidizing acids (crude commercial grade), where aqueous $\mathrm{pH}$ is decreased causing the metal(loid)s quite soluble in water (Sthiannopkao and Wong 2013).

\subsection{Soil Contamination}

Page 6/28 
The levels of hazardous metals $(\mathrm{Pb}, \mathrm{Cd}, \mathrm{Cu}, \mathrm{Zn}, \mathrm{As}, \mathrm{Hg}, \mathrm{Ni}$ and $\mathrm{Cr}$ ) were studied in vertical soil distribution (0-15 and 15-45 cm, bgl) sampled from open burning sites. The results are presented in tabular form (Tables 3-6). Briefly, the soil load of the hazardous metals sampled are often exceeding when compared with (Table 7) control site (Nishapur, nearby non-contaminated agricultural land).

The levels of $\mathrm{Cu}, \mathrm{Pb}$ and $\mathrm{Zn}$ in soil samples collected $(0-15 \mathrm{~cm})$ from all the sites often exceeded the Indian National Standard for soil (Cu: $135-270 \mathrm{mgkg}^{-1}, \mathrm{~Pb}: 250-500 \mathrm{mgkg}^{-1}, \mathrm{Zn}: 100-200 \mathrm{mgkg}^{-1}$ ) (IS2000). Moreover, $\mathrm{Cu}, \mathrm{Pb}$ and $\mathrm{Zn}$ levels also exceeded the USEPA standard (USEPA 2012) (Tables 3-7). In contrast, As, Hg, Ni, Cr generally do not exceed the USEPA standard (As: $12 \mathrm{mgkg}^{-1}, \mathrm{Hg}: 92 \mathrm{mgkg}^{-1}, \mathrm{Cr}: 400$ $\mathrm{mgkg}^{-1}$ ) (Abbasi et al. 2016). Field observations revealed that open burning of power cables have been done regularly to recover $\mathrm{Cu}, \mathrm{Pb}$ and $\mathrm{Zn}$ which ultimately resulted in overall contamination of the soil. As a result, $\mathrm{Cu}, \mathrm{Pb}$ and $\mathrm{Zn}$ are apparently accumulated in the soil as found in higher levels in the monitored sites. Additionally, acid stripping was noted to be a common process for recovery. These released acid wastes directly exposed to and impacted the soil environment, the levels of these metals detected was higher than the National standard for soil. Thus, comparison of results highlights the close relationship between the recycling work performed at the e-waste handling sites and the alarming accumulation of the elevated metals in soil.

Both the results (water and soil) showed variations in the levels of hazardous metals ( $\mathrm{Pb}, \mathrm{Cd}, \mathrm{Cu}, \mathrm{Zn}, \mathrm{As}$, $\mathrm{Hg}, \mathrm{Ni}$ and $\mathrm{Cr}$ ) in between monitored sites that is linked the type of e-waste openly burned. The e-waste involved were primarily PCB, CRT displays, power cables and plastics. They were dismantled manually followed by acid bathing in recycling sites. These factors may have catalytic effects on hazardous metal concentrations in soils and waters (Uchida et al. 2018).

The results also revealed that the hazardous metals in sampled soils from open burning sites are not presenting any clear picture regarding movement of metals in deeper soils (15-45 cm) (Tables 3-6). $\mathrm{Cu}, \mathrm{Pb}$ and $\mathrm{Cd}$ are predominantly increasing, whereas, $\mathrm{As}, \mathrm{Hg}, \mathrm{Ni}$ and $\mathrm{Cr}$ are not demonstrating such trends (Tables 3-6). In fact, Cd, Cu, Pb levels increasing up to 9, 2, 4 times respectively in the deeper soil with regard to pre-monsoon that are above the USEPA permissible limit (Fergusson 1990). Results suggested that $\mathrm{Cu}, \mathrm{Pb}, \mathrm{Cd}$ has contaminated the soil environment and a considerable level ( $\mathrm{Cu}$ up to $2328.60 \pm$ 217.60, $\mathrm{Pb}$ up to $342.90 \pm 32.36$ and $\mathrm{Cd} 18.34 \pm 3.81 \mathrm{mgKg}^{-1}$ ) of these hazardous metals had leached to subsurface layer $(15-45 \mathrm{~cm})$, and possibly moved into the deeper soil strata. An increase in mobility is possible alongside the increase in soil contamination with the enhanced levels of $\mathrm{Cu}, \mathrm{Pb}, \mathrm{Cd}$ (Fijałkowski et al. 2012). However, the downward movement of these hazardous metals are varied and ranked in the following decreasing order: $\mathrm{Cd}>\mathrm{Pb}>\mathrm{Cu}$. The downward movement is facilitated by water soluble forms of the respective metals (Ceballos and Dong 2016; Zhang et al. 2019). In this context, Cd is highly mobile in the soil-plant system and associated with high bioavailability and risk (Xing et al. 2009; Kumar and Rawat 2013). Pb may impose a moderate risk to water, soil and food chain whereas Cu may pose low risk both in terms of bioavailability and low uptake in food chain (Moral and Jordan 2005). As, $\mathrm{Hg}, \mathrm{Ni}$ and $\mathrm{Cr}$ were relatively restricted in downward movements when compared to $\mathrm{Cu}, \mathrm{Pb}$ and $\mathrm{Cd}$. The mobility of these hazardous metals was limited due to adsorption by clays (Alloway 1995). 
The seasonal variability of hazardous metals from open burning sites is also studied and summarized (Tables 3-6). The variability is clearly noted when Pre $M$ and Post $M$ levels are compared. However, the Pre $\mathrm{M}$ levels are usually higher than the Post $\mathrm{M}$ levels, with a few exceptions in $\mathrm{Pb}, \mathrm{Cu}, \mathrm{Cd}$ levels (Tables 3-6). The extent of variation was different in the monitored samples collected from various sites. For example, the levels of $\mathrm{Cu}(0-15 \mathrm{~cm})$ were higher in the Pre $\mathrm{M}$ and $\mathrm{Pb}, \mathrm{Cd}$ and $\mathrm{Zn}$ levels were higher in the Post M (Site 1, Table 3). In the deeper strata $(15-45 \mathrm{~cm})$ the metal distribution pattern was altered (Oluyemi et al. 2008). Here Pb, Cd, Zn, and Cu were relatively elevated in post-monsoon. Cd (Post M) and $\mathrm{Cu}$ (Pre/Post M) exceeded the safe values in comparison to the National Standard and the USEPA guideline values.

Similarly, $\mathrm{Pb}$ and $\mathrm{Cd}$, levels were elevated in both Pre/Post M samples (Site 2, Table 4). In this case, $\mathrm{Cu}$, $\mathrm{Zn}, \mathrm{As}, \mathrm{Hg}, \mathrm{Ni}$ and $\mathrm{Cr}$ were higher in Pre M samples when compared to Post M (Tian et al. 2006). Pb, Cd and $\mathrm{Cu}$ levels exceeded the safe values in regard to the National Standard and the USEPA guideline values. Similar variation was observed in case of $\mathrm{Pd}$ and $\mathrm{Cd}(0-15 \mathrm{~cm}$, Site 3, Table 5), whereas Cu, Zn, As, $\mathrm{Hg}, \mathrm{Ni}$ and $\mathrm{Cr}$ were relatively high in pre-monsoon. In deeper soil the scenario was unaltered (Tables 5 and 6).

The monsoonal impacts on the changes in metal levels were examined. Results revealed that during the Pre M season (dry, Nov-May) these hazardous metals had elevated levels as open dumping and burning of e-waste are a common practice. However, $\mathrm{Pb}, \mathrm{Cd}$ and occasionally $\mathrm{Cu}$ were found to be elevated in Post $\mathrm{M}$ season. The results highlighted that the origin of the handled e-waste in those monitored sites along with the process of open burning influenced the level of the metal(loid) present in the soil and water environment. The earlier studies in SE Asia also revealed that toxic and hazardous metals regularly emitted from e-waste informal recycling centers. Those studies demonstrated pollution in the air, water and soil environment and also plants and human uptake (Table 8).

During continuous flooding, inundated soil pH increased while redox potential $\left(E_{h}\right)$ decreased over time (Vaněk et al. 2005; Oluyemi et al. 2008). The prolonged water-logged condition results in enriched Pd, $\mathrm{Cu}$ and, $\mathrm{Cd}$ levels in pore water, where controlling factors are $\mathrm{pH}, \mathrm{E}_{\mathrm{h}}$, presence of $\mathrm{Fe}$, dissolved organic matter and presence of oxic ions (Vaněk et al. 2005). Consequently, a gradual migration of more labile forms of these hazardous metals (in this case $\mathrm{Pb}, \mathrm{Cu}, \mathrm{Cd}$ ) and their intensive accumulation could result in their downward movement, notably in the Post M season (Pan et al. 2021). In this regard, metal chemical forms (mostly water soluble) and their higher mobility were majorly responsible for transfer to soil environment (Pan et al. 2021), and dependent on their chemical nature, mobility coefficient, enrich levels and favourable soil environment (Pan et al. 2021). After rainfall the concentrations of heavy metals were higher in deeper strata $(15-45 \mathrm{~cm}$ ) due to downward percolation (Sherene et al. 2010).

It was observed that the concentrations of heavy metals were much higher in the topsoil than the sub soil due to anthropogenic activities (Israel et al. 2004; Chidi and Osibanjo 2008). It was observed that after rainy days, dismantling activities intensify. Approximately 30-40 kgs of e-wastes were dismantled in 3-4 days around that time. The obsolete e-items (e.g., CRT) were the major sources of Pb and $\mathrm{Cd}$ and 
attributed to the elevated concentration of these two elements in the soil samples. Other variations were due to the different nature of the e-waste being handled.

\section{Microscale E-waste Management - Challenges And Implications}

In India, the fundamental and comprehensive e-waste management was first introduced in the form of "Ewaste Management and Handling Rules, 2011" (MoEF 2011). The legislation proposed Extended Producer Responsibility (EPR) to overcome the challenges of e-waste management, notably in the microscale informal sectors. This is deemed to be an essential prerequisite to ensure the efficient management of e-waste advocating the safe and environment friendly ways of handling, transportation, storage, and recycling.

The concept of EPR puts the onus on the manufacturers for the management of the final life of EEE products. State pollution control boards were identified to create norms and necessary environment to manage the e-waste. However, the legislation did not set collection targets, resulting major obstacle for ground level implementation (MoEF 2016). The e-waste management rule was amended in 2016 and reintroduced in 2017. The EEE items dealer/manufacturer/refurbisher and Producer Responsibility Organization (PRO) were also brought under the purview of the 2017 legislations. The legislation also expanded to examine the parts/spares/components/consumables of EEE items in addition to the equipment (MoEF 2016). These amendments were made with the aims to outlet the e-waste generated in the country en route to approved recyclers/handlers/traders in order to cater the 'Formal Sector'. The legislation had another mandate with regard to EEE items to return back their sold EEE items to the dealer /manufacturer with regulated mechanisms. The EPR collection targets were amended and introduced for manufactures because they commercialized those products. The PRO is a professional organization authorized or financed collectively or individually by producers. The PRO has the responsibility for collection and channelization of e-waste (end-of-life products) to guarantee eco-friendly options managing the waste in the entire country.

However, it has been observed that though there has been a notable augmentation in the formal e-waste processing capacity after the implementation of the Rules, only a meagre percentage of the total waste generated (5-15\%) is likely to get processed through formal sector. The EPR framework forced the producers to address only a few relatively less significant aspects of the Rules. The collection and recycling system has not been made accessible for the consumers to dispose their e-waste in formal collection and recycling units. It can be aptly argued that the concept of EPR in India should surpass simple take-back mandates and must concentrate into other policy instruments e.g. deposit-refund system, which has been introduced as an additional economic instrument within the ambit of 2017 legislation. This system means a scheme whereby the EEE producer charges an additional amount as a deposit while selling the equipment and returns it to the consumer along with the interest when the endof-life EEE is returned. 
The horizon of EEEs brought under these 2017 rules is also expanded by the incorporation of few more items viz. compact fluorescent lamp (CFL) and other mercury bearing lamps. The term 'Bulk Consumer' is redefined by the addition of 'healthcare facilities' which have turnover of more than $\sim 1$ million or have more than 20 employees.

The amended law provided the assurance in this effect that the manufactures/producers of each EEE item should certify that their equipment, including their components or consumables or parts or spares, should comply with the standards as per prescribed by the 2017 rule with regard to hazardous metals/substances [ $\mathrm{Cd}, \mathrm{Hg}, \mathrm{Pb}, \mathrm{Cr}(\mathrm{VI})$, polybrominated biphenyls and polybrominated diphenyl]. The legislation asked individual manufactures/producers to make detailed information on the constituents of the equipment and their components or consumables or parts or spares. The legislation has further made a provision for declaration of conformity regarding the Restricted Use of Hazardous Substances (RoHS, Restriction of Hazardous Substances) provisions in the product user documentation. Import or assignment regarding new EEE items could only be permitted under the provision of sub-rules ( 1 and 4 ) and rule (16) when compliance under restricted condition (MoEF 2016).

The legislation (2017) was further amended in 2018 to address the lacunas in the existing rules and to make efforts towards sustainable environmental goals. The collection targets were revised. The quantity of waste generated $(10 \%, 2017-2018)$ shall be collected and every year there shall be an increase to the extent of $10 \%$ till the year 2023. Beyond the target year (2023), the collection target has been fixed to be $70 \%$ of the generated quantity of e-waste.

In reality, the manufactures/producers have to be accountable for their product for skillful implementation of the amended e-waste laws. A coordinated effort is essential to bring manufactures/producers, PCBs (both central and state) and local authorities under the same umbrella putting the e-waste management in right track. The major challenge is to meet the realistic e-waste collection targets with increased efficiency at the microscale informal sectors. Appropriate registration of PROs is another legitimate step towards paving the way for skillful and improved e-waste management in India.

At this juncture, special management skills are needed to put forward the implementation of e-waste amended rules for the purpose of improvement of the microscale ground reality. From this perspective a scheme is proposed following a holistic approach for the improvement of e-waste management in southeast Asian countries (Fig. 5). Several influencing factors such as numerous inputs and their connectivity, role of local authorities (municipality and panchayat), surveillance support by enforcing agencies (PCB), role of producers and consumers, importance of formal sector and task of interface organizations (public awareness, registration, tracking of e-waste) are focused and summarized (Fig. 5). This will provide a new roadmap and maximize the benefit in terms of environment and human health protection.

This approach proposes that reuse, refurbishment, dismantling and recycling practices that should be continued in the informal sector due to two-fold reasons. Firstly, the workers at these sectors should be allowed to earn their livelihood. Secondly, these processes should be relatively less hazardous in terms of 
environment and health viewpoint. However, at all stages surveillance from the part of the law enforcing agencies (CPCB and SPCB) should be made mandatory to generate awareness on shifting the focus from informal to formal sector (Dwivedy et al. 2015). Government may propose a proper regulation for PROs so that the end product supply chain is systematically channelized from microscale informal sectors to recognized formal sectors (Wath et al. 2010).

Presently, developed countries like Switzerland has introduced Advance Recycle Fee (ARF) system and such fees can be revised/reset based on the categorization of the electrical and electronic goods, expert views and regular consultation with the industry (Hischier et al. 2005; Khetriwal et al. 2009). The present study proposes that industries should be intensely involved with technical expert groups to build up an effective ARF system, along with its maintenance and periodic revision. An apex body will help maintaining the interconnectivity between consumers and producers and appraising Government, so that existing rules can be modified or regulated in terms of ARF, eco-labelled product and collection center as and when required.

Last but not the least, the proposed scheme may also lead society towards the goal of sustainable development when stakeholders, producers, consumers, and handlers of e-waste will interact according to the scheme of e-waste management in the microscale informal sectors. Although the amended laws in India have come into place, the microscale informal sector has overall control on e-waste handling and disposal, which is to be continued at the cost of huge health and environmental cost polluting ground water and soil. In this context, the proposed improved e-waste management practice will be a new roadmap for several south-east Asian countries to protect the eco-system and human health, including microscale informal sites in India such as the one monitored in this study.

\section{Conclusion}

Water and soil samples have elevated levels of monitored hazardous metal(loid)s ( $\mathrm{Pb}, \mathrm{Cd}, \mathrm{Cu}, \mathrm{Zn}, \mathrm{As}, \mathrm{Hg}$, $\mathrm{Ni}$ and $\mathrm{Cr}$ ). However, the concentrations are consistently low to very low in the water environment, suggesting restricted dissolution of harmful metal(loid)s. However, $\mathrm{Cd}, \mathrm{Pb}$ and As are detected above national drinking water safe limit. Consequently, the public health risk is associated with pond waters that used for e-waste handling/dismantling. Because these ponds are usually flooded during the monsoon season and may mix with further larger water resources. On the other hand, the monitored soil samples (both top and subsoil) are consistently dominated with enriched levels of hazardous metal(loid)s (e.g., $\mathrm{Pd}, \mathrm{Cd}$ and $\mathrm{Cu}$ ) when compared to the control site. This could impose a future risk in terms of accumulation and biomagnification of these metal(loid)s through various routes, e.g., water or food crops. Moreover, soil pollution may remain a matter of concern, as the chemical behaviour (availability of relatively mobile soluble form and oxidation state) may play a key role to mobilize the metals in subsurface environment.

The seasonal variations were clearly evident as well. The Post M (June-Oct) levels were high in Pd, Cd and $\mathrm{Cu}$ levels than the Pre $\mathrm{M}$ season. The variation, distribution, and behaviour of monitored hazardous 
metal(loid)s primarily depend on the type of e-waste being processed and the manual handling/sorting/separating/dismantling/treatment method seemed to have a great influence on the levels of hazardous metal(loid)s being released in the ambient environment.

In India, the e-waste legislation (2011) and subsequent amendments $(2016,2017,2018)$ are already implemented. However, the microscale informal sector environmental perspective (almost) remains unchanged. In this context, a skillful e-waste management model has been designed to accelerate the implementation process to ensure rapid growth of formal sectors and quick abolition of informal sectors, notably open burning. The model accommodates several judicious steps (connectivity among key players, strengthening local authorities, strong surveillance, public awareness, and producer/consumer relationship) to face the challenges, a grey area of e-waste management in entire south-east Asia.

\section{Statements And Declarations}

\section{Acknowledgement}

D.D. is thankful to the scholarship provided by the UGC-BSR scheme, Govt. of India. S.M. would like to thank the European Commission for the Marie Curie-Sklowdowska Post-Doctoral Fellowship (Project Reference H2020-MSCA-IF-2020 - 101031051).

\section{Compliance with Ethical Standards}

There are no potential conflicts of interest. This research work does not involve any human participants and/or animals.

\section{Consent to publish}

All authors approved the final manuscript for submission and publication.

\section{Authors contributions}

Debashis Chatterjee and Santanu Majumder contributed to the study conception and design. Material preparation, Experimental analysis, data collection and material preparation were performed by Dipsikha Dasgupta, Santanu Majumder and Debashis Chatterjee. The first draft of the manuscript was written by Dipsikha Dasgupta, followed by rigorous detailed revisions by Debashis Chaterjee and Santanu Majumder. Jishnu Adhikari, Pinaki Ghosh, Diane Purchase, Hemda Garelick, Anupam Debsarkar - they all have been intellectually involved during the primary inception of the study and commented on previous versions of the manuscript. All authors read and approved the final manuscript.

\section{Funding}

This work was supported by UGC-PURSE, Govt. of India. D.D. is thankful to the scholarship provided by the UGC-BSR scheme, Govt. of India. S.M. would like to thank the European Commission for the Marie Curie-Sklowdowska Post-Doctoral Fellowship (Project Reference H2020-MSCA-IF-2020 - 101031051). 


\section{Data availability}

All data generated or analyzed during this study are included in this article.

\section{Competing interests}

The authors have no relevant financial or non-financial interests to disclose.

\section{References}

1. Abbasi G, Saini A, Goosey E, Diamond ML (2016) Product screening for sources of halogenated flame retardants in Canadian house and office dust. Sci Tot Environ 545:299-307

2. Alloway BJ (1995) Heavy metals in soils. Blackie Academic and Professional. An Imprint of Chapman \& Hall. Glasgow

3. Awasthi AK, Zeng X, Li J (2016) Environmental pollution of electronic waste recycling in India: A critical review. Environ Pollut 211:259-270

4. Baird RB, Eaton AD, Rice EW, Bridgewater $L$ (2017) Standard methods for the examination of water and wastewater (Vol. 23). Washington, DC: American Public Health Association

5. Baldé CP, Wang F, Kuehr R, Huisman J (2015) The global e-waste monitor-2014, United Nations University, IAS. Bonn (Germany): SCYCLE

6. BIS (2012). Indian standard drinking water-specification (second revision) IS: 10500, Bureau of Indian Standards

7. Caravanos J, Clark E, Fuller R, Lambertson C (2011) Assessing worker and environmental chemical exposure risks at an e-waste recycling and disposal site in Accra, Ghana. J Health Pollut 1:16-25

8. Ceballos DM, Dong Z (2016) The formal electronic recycling industry: Challenges and opportunities in occupational and environmental health research. Environ Int 95:157-166

9. Chen A, Dietrich KN, Huo X, Ho SM (2011) Developmental neurotoxicants in e-waste: an emerging health concern. Environ Health Persp 119:431-438

10. Dasgupta D, Debsarkar A, Chatterjee D, Gangopadhyay A (2014) E-waste management in India: Issues and concern. J Int Environ Appl Sci 9:257-261

11. Dasgupta D, Debsarkar A, Chatterjee D, Gangopadhyay A, Chatterjee D (2015) Present E-waste handling and disposal scenario in India: planning for future management. Int J Eng Res Appl 5:99107

12. Dasgupta D, Debsarkar A, Hazra T, Bala BK, Gangopadhyay A, Chatterjee D (2017) Scenario of future e-waste generation and recycle-reuse-landfill-based disposal pattern in India: a system dynamics approach. Environ Dev Sustain 19:1473-1487

13. Dimitrakakis E, Janz A, Bilitewski B, Gidarakos E (2009) Determination of heavy metals and halogens in plastics from electric and electronic waste. Waste Manage 29:2700-2706 
14. Dwivedy M, Mittal RK (2010) Estimation of future outflows of e-waste in India. Waste Manage 30:483-491

15. Dwivedy M, Suchde P, Mittal RK (2015) Modeling and assessment of e-waste take-back strategies in India. Resour Conserv Recy 96:11-18

16. Eguchi A, Nomiyama K, Tue NM, Trang PTK, Viet PH, Takahashi S, Tanabe S (2015) Residue profiles of organohalogen compounds in human serum from e-waste recycling sites in North Vietnam: association with thyroid hormone levels. Environ Res 137:440-449

17. Erickson MD, Kaley RG (2011) Applications of polychlorinated biphenyls. Environ Sci Pollut Res 18:135-151

18. Fergusson JE (1990) The heavy elements: chemistry, environmental impact adn health effects $\backslash$ Jack E. Fergusson (No. 628.53 F4.).

19. Fijałkowski K, Kacprzak M, Grobelak A, Placek A (2012) The influence of selected soil parameters on the mobility of heavy metals in soils. Inżynieria i Ochrona środowiska, 15:81-92

20. Fu J, Zhou Q, Liu J, Liu W, Wang T, Zhang Q, Jiang G (2008) High levels of heavy metals in rice (Oryzasativa L.) from a typical E-waste recycling area in southeast China and its potential risk to human health. Chemosphere 71:1269-1275

21. Fujimori T, Takigami H, Agusa T, Eguchi A, Bekki K, Yoshida A, Ballesteros Jr, FC (2012). Impact of metals in surface matrices from formal and informal electronic-waste recycling around Metro Manila, the Philippines, and intra-Asian comparison. J Hazard Mater 221:139-146

22. Garlapati VK (2016) E-waste in India and developed countries: Management, recycling, business and biotechnological initiatives. Renew Sust Energ Rev 54:874-881

23. Gidarakos E, Basu S, Rajeshwari KV, Dimitrakakis E, Johri CR (2012) E-waste recycling environmental contamination: Mandoli, India. In Proceedings of the Institution of Civil Engineers-Waste and Resource Management (Vol. 165, No. 1, pp. 45-52). ICE Publishing

24. Guha Thakurata G (2015) Land problem for formation of e-waste plant (in Bengali), Anandabazar

25. Hischier R, Wäger P, Gauglhofer J (2005) Does WEEE recycling make sense from an environmental perspective?: The environmental impacts of the Swiss take-back and recycling systems for waste electrical and electronic equipment (WEEE). Environ Impact Assess Rev 25:525-539

26. Ikhlayel M (2016) Differences of methods to estimate generation of waste electrical and electronic equipment for developing countries: Jordan as a case study. Resour Conserv Recy 108:134-139

27. Indian Standard Code in Soil for Permissible limit (IS -2000)

28. Isimekhai KA, Garelick H, Watt J, Purchase D (2017) Heavy metals distribution and risk assessment in soil from an informal E-waste recycling site in Lagos State, Nigeria. Environ Sci Pollut Res 24:17206-17219

29. Khetriwal DS, Kraeuchi P, Widmer R (2009) Producer responsibility for e-waste management: key issues for consideration-learning from the Swiss experience. J Environ Manage 90:153-165

30. The Hindu (2014) Kolkata among top e-waste producers. Kolkata 
31. Kumar S, Rawat S (2013) E-inventory for proactive e-waste management. In Proceedings of the 7th International Conference on Theory and Practice of Electronic Governance (pp. 112-115)

32. Li J, Tian B, Liu T, Liu H, Wen X, Honda SI (2006) Status quo of e-waste management in mainland China. J Mater Cycles Waste Manage 8:13-20

33. Liu H, Zhou Q, Wang Y, Zhang Q, Cai Z, Jiang G (2008) E-waste recycling induced polybrominated diphenyl ethers, polychlorinated biphenyls, polychlorinated dibenzo-p-dioxins and dibenzo-furans pollution in the ambient environment. Environ Int 34:67-72

34. Maris $E$, Botané $P$, Wavrer $P$, Froelich D (2015) Characterizing plastics originating from WEEE: A case study in France. Miner Eng 76:28-37

35. Ministry of Environment, Forests (MOEF) (2011) "E-waste (Handling and Management) Rules, 2011"

36. Ministry of Environment, Forests (MOEF) (2016) "E-waste (Handling and Management) Rules, 2016"

37. Monika JK (2010) E-waste management: as a challenge to public health in India. Indian journal of community medicine: official publication of Indian Association of Preventive \& Social Medicine $35: 382$

38. Moral R, Gilkes RJ, Jordán MM (2005) Distribution of heavy metals in calcareous and noncalcareous soils in Spain. Water Air Soil Poll 162:127-142

39. Nandi J (2010) Will a Draft Law Reboot e-Mess?. The Times of India, New Delhi

40. Nnorom IC, Osibanjo O (2008) Electronic waste (e-waste): Material flows and management practices in Nigeria. Waste Manage 28:1472-1479

41. Oluyemi EA, Feuyit G, Oyekunle JAO, Ogunfowokan AO (2008) Seasonal variations in heavy metal concentrations in soil and some selected crops at a landfill in Nigeria. Afr J Environ Sci Technol 2:89-96

42. Ongondo FO, Williams ID, Cherrett TJ (2011) How are WEEE doing? A global review of the management of electrical and electronic wastes. Waste Manage 31:714-730

43. Pan Y, Chen J, Gao K, Lu G, Ye H, Wen Z, Dang Z (2021) Spatial and temporal variations of Cu and Cd mobility and their controlling factors in pore water of contaminated paddy soil under acid mine drainage: A laboratory column study. Sci Tot Environ 148523.

44. Pikuła D, Stępień W (2021) Effect of the Degree of Soil Contamination with Heavy Metals on Their Mobility in the Soil Profile in a Microplot Experiment. Agronomy 11:878

45. Purchase D, Abbasi G, Bisschop L, Chatterjee D, Ekberg C, Ermolin, M. Wong MH (2020) Global occurrence, chemical properties, and ecological impacts of e-wastes (IUPAC Technical Report). Pure and Applied Chemistry, 92:1733-1767

46. Razo I, Carrizales L, Castro J, Díaz-Barriga F, Monroy M (2004) Arsenic and heavy metal pollution of soil, water and sediments in a semi-arid climate mining area in Mexico. Water Air Soil Poll 152:129152

47. Rigoldi A, Trogu EF, Marcheselli GC, Artizzu F, Picone N, Colledani M, Deplano P, Serpe A (2018) Advances in recovering noble metals from waste printed circuit boards (WPCBs). ACS Sustain Chem 
Eng 7:1308-1317

48. Satyamurty K (2006) Managing e-waste without harming environment. The Hindu

49. Schlummer M, Gruber L, Mäurer A, Wolz G, Van Eldik, R (2007) Characterization of polymer fractions from waste electrical and electronic equipment (WEEE) and implications for waste management. Chemosphere 67:1866-1876

50. Secretariat Report (2007) E-waste management. Maharashtra Pollution Control Board

51. Secretariat Report (2010) E-waste management. West Bengal Pollution Control Board

52. Secretariat Report (2011) E-waste in India. India Research Unit (Larrdis), Rajya Sabha Secretariat, New Delhi

53. Sherene T (2010) Mobility and transport of heavy metals in polluted soil environment. In Biological Forum - An International Journal (Vol. 2, No. 2, pp. 112-121)

54. Sthiannopkao S, Wong MH (2013) Handling e-waste in developed and developing countries: Initiatives, practices, and consequences. Sci Tot Environ 463:1147-1153

55. Toxic Link India (2007) Mumbai: Choking on e-Waste-A Study on the Status of e-Waste in Mumbai

56. Uchida N, Matsukami H, Someya M, Tue NM, Viet PH, Takahashi S, Tanabe S. Suzuki G (2018) Hazardous metals emissions from e-waste-processing sites in a village in northern Vietnam. Emerging Contaminants, 4(1), pp.11-21.

57. United States Environmental Protection Agency (USEPA) (2012) Hazardous Site Control Division. Soil Standard (Superfund Soil Screening Guidance.)

58. Vaněk A, Borůvka L, Drábek O, Mihaljevič M. Komárek M (2005) Mobility of lead, zinc and cadmium in alluvial soils heavily polluted by smelting industry. Plant Soil Environ 51:316-321

59. Vazquez YV, Barbosa SE (2017) Compatibilization strategies for recycling applications of high impact polystyrene/acrylonitrile butadiene blends. J Polym Environ 25:903-912

60. Wath SB, Dutt PS, Chakrabarti T (2011) E-waste scenario in India, its management and implications. Environ Monitor Assess 172:249-262

61. Wath SB, Vaidya AN, Dutt PS, Chakrabarti T (2010) A roadmap for development of sustainable Ewaste management system in India. Sci Tot Environ 409:19-32

62. World Health Organization (WHO) (2008) Guidelines for drinking-water quality: second addendum. Vol. 1, Recommendations

63. Xing GH, Chan JKY, Leung AOW, Wu SC, Wong MH (2009) Environmental impact and human exposure to PCBs in Guiyu, an electronic waste recycling site in China. Environ Int 35:76-82

64. Young E (2004) E-Waste in Chennai Time Is Running out; Toxics Link: New Delhi, India

65. Zhang M, Shi J, Meng Y, Guo W, Li H, Liu X, Zhang Y, Ge H, Yao M, Hu Q (2019) Occupational exposure characteristics and health risk of PBDEs at different domestic e-waste recycling workshops in China. Ecotox Environ Safe 174:532-539.

66. Zheng L, Wu K, Li Y, Qi Z, Han D, Zhang B, Gu C, Chen G, Liu J, Chen S, Xu X (2008) Blood lead and cadmium levels and relevant factors among children from an e-waste recycling town in China. 
Environ Res 108:15-20.

\section{Tables}

Table 1: Classification of e-waste (revised EU WEEE Directives) modified after [7].

No. Types

1. Temperature exchange equipment

2. Screens and monitors (surface area $>100 \mathrm{~cm}^{2}$ )

3. Lamps

4. Large equipment (any external dimension $>50 \mathrm{~cm}$ )

5. Small equipment (external dimension $\leq 50 \mathrm{~cm}$ )

6. Small IT and telecommunication equipment (external dimension $\leq 50 \mathrm{~cm}$ )

EU WEEE - European Union Waste Electrical and Electronic Equipment

Table 2: Hazardous Metal(loid)s Contamination in Pond Water. 


\begin{tabular}{|c|c|c|c|c|c|c|c|c|}
\hline \multirow{2}{*}{$\begin{array}{l}\text { Heavy Metals } \\
\left(\mathrm{mgL}^{-1}\right)\end{array}$} & \multicolumn{2}{|l|}{ Site 1} & \multicolumn{2}{|l|}{ Site 2} & \multicolumn{2}{|l|}{ Site 3} & \multicolumn{2}{|l|}{ Site 4} \\
\hline & PreM & PostM & PreM & Post M & PreM & $\begin{array}{l}\text { Post } \\
\text { M }\end{array}$ & PreM & PostM \\
\hline \multirow{2}{*}{$\begin{array}{l}\text { Cadmium } \\
\text { (Cd) }\end{array}$} & \multirow{2}{*}{$\begin{array}{l}0.006 * \\
\pm 0.002\end{array}$} & \multirow{2}{*}{$\begin{array}{l}0.001 \\
\pm 0.001\end{array}$} & \multirow{2}{*}{$\begin{array}{l}0.041 * \\
\pm 0.016\end{array}$} & \multirow{2}{*}{$\begin{array}{l}0.009 \\
* \\
\pm 0.004\end{array}$} & \multirow{2}{*}{$\begin{array}{l}0.009 \\
* \\
\pm 0.003\end{array}$} & \multirow{2}{*}{$\begin{array}{l}0.003 \\
\pm 0.001\end{array}$} & \multirow{2}{*}{$\begin{array}{l}0.004 * \\
\pm 0.003\end{array}$} & \multirow{2}{*}{$\begin{array}{l}0.003 \\
\pm 0.0011\end{array}$} \\
\hline & & & & & & & & \\
\hline \multirow[t]{2}{*}{$\mathrm{Se}$} & 0.010 & 0.008 & 0.009 & 0.008 & 0.009 & 0.008 & 0.011 & 0.009 \\
\hline & \pm 0.004 & \pm 0.003 & \pm 0.004 & \pm .003 & \pm 0.003 & \pm 0.003 & \pm 0.004 & \pm 0.004 \\
\hline \multirow[t]{2}{*}{$\mathrm{Zn}$} & 0.280 & 0.013 & 1.81 & 0.036 & 0.20 & 0.131 & 0.063 & 0.005 \\
\hline & \pm 0.14 & \pm 0.007 & \pm 0.71 & \pm 0.018 & \pm 0.071 & \pm 0.074 & \pm 0.022 & \pm 0.002 \\
\hline \multirow[t]{2}{*}{$\mathrm{Pb}$} & 1.620 * & $\underset{*}{0.034}$ & & $\underset{*}{0.074}$ & 0.780 * & $0.183^{*}$ & $0.067 *$ & 0.01 \\
\hline & \pm 0.77 & & $\stackrel{ \pm}{0.505}$ & \pm 0.003 & \pm 0.340 & \pm 0.075 & \pm 0.022 & \pm 0.003 \\
\hline \multirow[t]{2}{*}{$\mathrm{Hg}$} & 0.001 & 0.008 & 0.003 & 0.001 & $0.008^{*}$ & 0.001 & $0.009 *$ & $0.009 *$ \\
\hline & \pm 0.008 & \pm 0.003 & \pm 0.001 & \pm 0.003 & \pm 0.003 & \pm 0.005 & \pm 0.004 & \pm 0.00028 \\
\hline \multirow[t]{2}{*}{$\mathrm{Ni}$} & 0.020 & 0.018 & 0.023 & 0.019 & 0.023 & 0.0195 & 0.0198 & 0.014 \\
\hline & \pm 0.007 & \pm 0.005 & \pm 0.011 & \pm 0.01 & \pm 0.007 & \pm 0.009 & \pm 0.007 & \pm 0.005 \\
\hline \multirow[t]{2}{*}{ As } & 0.030 * & 0.010 & 0.009 & 0.008 & 0.01 * & 0.007 & 0.01 & 0.009 \\
\hline & \pm 0.02 & \pm 0.004 & \pm 0.003 & \pm 0.003 & \pm 0.004 & \pm 0.005 & \pm 0.004 & \pm 0.003 \\
\hline \multirow[t]{2}{*}{$\mathrm{Cu}$} & 1.40 & 0.076 & 0.042 & 0.009 & 0.590 & 0.337 & 0.032 & 0.024 \\
\hline & \pm 0.66 & \pm 0.051 & \pm 0.016 & \pm 0.003 & \pm 0.236 & \pm 0.148 & \pm 0.02 & \pm 0.011 \\
\hline \multirow[t]{2}{*}{$\mathrm{Cr}^{+6}$} & 0.030 & 0.007 & 1.74 & 0.041 & $0.120 *$ & $0.096^{*}$ & 0.013 & 0.009 \\
\hline & \pm 0.011 & \pm 0.002 & \pm 0.794 & \pm 0.018 & \pm 0.044 & \pm 0.04 & \pm 0.005 & \pm 0.003 \\
\hline
\end{tabular}

Table 3: Hazardous Metal (loid)s Contamination in soil (Site 1, Mean \pm SD)

Table 4: Hazardous Metal (loid)s Contamination in soil (Site 2, Mean \pm SD) 


\begin{tabular}{|c|c|c|c|c|c|}
\hline \multirow[t]{2}{*}{ Parameter } & \multicolumn{2}{|l|}{ Depth 0-15 cm } & \multicolumn{2}{|l|}{ Depth $15-45 \mathrm{~cm}$} & \multirow{2}{*}{$\begin{array}{l}\text { USEPA } \\
\text { Standard } \\
(\mathrm{mg} / \mathrm{kg})\end{array}$} \\
\hline & $\begin{array}{l}\text { Pre-monsoon } \\
\text { in } \mathrm{mg} / \mathrm{kg}\end{array}$ & $\begin{array}{l}\text { Post- } \\
\text { monsoon } \\
\text { in } \mathrm{mg} / \mathrm{kg}\end{array}$ & $\begin{array}{l}\text { Pre-monsoon } \\
\text { in mg/kg }\end{array}$ & $\begin{array}{l}\text { Post- } \\
\text { monsoon } \\
\text { in } \mathrm{mg} / \mathrm{kg}\end{array}$ & \\
\hline Lead $(\mathrm{Pb})$ & $\begin{array}{r}637.80 \\
\pm 63.70\end{array}$ & $710 \pm 69.60$ & $\begin{array}{l}90.60 \pm \\
12.90\end{array}$ & $\begin{array}{l}191.90 \pm \\
16.40\end{array}$ & 300 \\
\hline $\begin{array}{l}\text { Cadmium } \\
\text { (Cd) }\end{array}$ & $1.90 \pm 0.20$ & $11.40 \pm 4.07$ & $1.19 \pm 0.59$ & $3.85 \pm 1.75$ & 3.0 \\
\hline Copper (Cu) & $\begin{array}{l}2576.10 \pm \\
255.80\end{array}$ & $\begin{array}{l}1908.90 \pm \\
95.43\end{array}$ & $\begin{array}{l}1634.30 \pm \\
101.8\end{array}$ & $\begin{array}{c}1376.0 \pm \\
422.8\end{array}$ & 50 \\
\hline Zinc (Zn) & $153.70 \pm 38.40$ & $\begin{array}{l}168.70 \pm \\
19.40\end{array}$ & $\begin{array}{l}63.10 \pm \\
15.60\end{array}$ & $\begin{array}{l}88.50 \pm \\
28.10\end{array}$ & 200 \\
\hline Arsenic (As) & $14.69 \pm 4.08$ & $11.60 \pm 3.36$ & $7.37 \pm 1.51$ & $5.80 \pm 1.81$ & - \\
\hline $\begin{array}{l}\text { Mercury } \\
(\mathrm{Hg})\end{array}$ & $0.09 \pm 0.01$ & $0.05 \pm 0.04$ & $0.07 \pm 0.02$ & $0.03 \pm 0.02$ & - \\
\hline Nickel (Ni) & $69.60 \pm 17.10$ & $38.70 \pm 5.69$ & $46.40 \pm 16.20$ & $17.28 \pm 4.11$ & - \\
\hline $\begin{array}{l}\text { Chromium } \\
\text { (Cr) }\end{array}$ & $0.70 \pm 0.18$ & $0.55 \pm 0.13$ & $0.19 \pm 0.05$ & $0.16 \pm 0.04$ & 400 \\
\hline
\end{tabular}




\begin{tabular}{|c|c|c|c|c|c|}
\hline \multirow[t]{2}{*}{ Parameter } & \multicolumn{2}{|l|}{ Depth $0-15 \mathrm{~cm}$} & \multicolumn{2}{|c|}{ Depth $15-45 \mathrm{~cm}$} & \multirow{2}{*}{$\begin{array}{l}\text { USEPA } \\
\text { Standard } \\
(\mathrm{mg} / \mathrm{kg})\end{array}$} \\
\hline & $\begin{array}{l}\text { Pre-monsoon } \\
\text { in } \mathrm{mg} / \mathrm{kg}\end{array}$ & $\begin{array}{l}\text { Post-monsoon } \\
\text { in } \mathrm{mg} / \mathrm{kg}\end{array}$ & $\begin{array}{l}\text { Pre-monsoon } \\
\text { in } \mathrm{mg} / \mathrm{kg}\end{array}$ & $\begin{array}{l}\text { Post-monsoon } \\
\text { in } \mathrm{mg} / \mathrm{kg}\end{array}$ & \\
\hline \multirow[t]{2}{*}{ Lead $(\mathrm{Pb})$} & 1323.30 & 1756.80 & 77.70 & 342.90 & \multirow[t]{2}{*}{300} \\
\hline & \pm 115.60 & \pm 161.24 & \pm 7.64 & \pm 32.36 & \\
\hline $\begin{array}{l}\text { Cadmium } \\
\text { (Cd) }\end{array}$ & $1.89 \pm 0.96$ & $14.18 \pm 4.11$ & $1.39 \pm 0.69$ & $6.40 \pm 2.43$ & 3.0 \\
\hline Copper (Cu) & $\begin{array}{l}4190.00 \pm \\
348.90\end{array}$ & $\begin{array}{l}2491.40 \pm \\
276.20\end{array}$ & $\begin{array}{l}1900.60 \pm \\
95.70\end{array}$ & $\begin{array}{l}1651.00 \pm \\
151.83\end{array}$ & 50 \\
\hline \multirow[t]{2}{*}{ Zinc (Zn) } & $455.7 \pm$ & $237.8 \pm$ & \multirow{2}{*}{$\begin{array}{l}134.40 \pm \\
33.40\end{array}$} & \multirow{2}{*}{$\begin{array}{l}100.70 \pm \\
23.64\end{array}$} & \multirow[t]{2}{*}{200} \\
\hline & 76.3 & 59.3 & & & \\
\hline Arsenic (As) & $15.93 \pm 2.86$ & $13.75 \pm 3.28$ & $2.81 \pm 0.091$ & $1.77 \pm 1.54$ & - \\
\hline $\begin{array}{l}\text { Mercury } \\
(\mathrm{Hg})\end{array}$ & $0.09 \pm 0.44$ & $0.06 \pm 0.09$ & $0.08 \pm .02$ & $0.06 \pm 0.03$ & - \\
\hline Nickel (Ni) & $35.40 \pm 8.76$ & $27.20 \pm 12.68$ & $23.72 \pm 3.29$ & $20.36 \pm 4.47$ & - \\
\hline $\begin{array}{l}\text { Chromium } \\
\text { (Cr) }\end{array}$ & $0.55 \pm 0.14$ & $0.24 \pm 0.11$ & $0.15 \pm 0.06$ & $0.12 \pm 0.07$ & 400 \\
\hline
\end{tabular}

Table 5: Hazardous Metal(loid)s Contamination in soil (Site 3 ,Mean \pm SD) 


\begin{tabular}{|c|c|c|c|c|c|}
\hline \multirow[t]{2}{*}{ Parameter } & \multicolumn{2}{|l|}{ Depth $0-15 \mathrm{~cm}$} & \multicolumn{2}{|c|}{ Depth $15-45 \mathrm{~cm}$} & \multirow{2}{*}{$\begin{array}{l}\text { USEPA } \\
\text { Standard } \\
(\mathrm{mg} / \mathrm{kg})\end{array}$} \\
\hline & $\begin{array}{l}\text { Pre-monsoon } \\
\text { in } \mathrm{mg} / \mathrm{kg}\end{array}$ & $\begin{array}{l}\text { Post- } \\
\text { monsoon } \\
\text { in } \mathrm{mg} / \mathrm{kg}\end{array}$ & $\begin{array}{l}\text { Pre-monsoon } \\
\text { in } \mathrm{mg} / \mathrm{kg}\end{array}$ & $\begin{array}{l}\text { Post-monsoon } \\
\text { in } \mathrm{mg} / \mathrm{kg}\end{array}$ & \\
\hline Lead $(\mathrm{Pb})$ & $\begin{array}{l}1648.70 \pm \\
128.74\end{array}$ & $\begin{array}{l}1853.33 \pm \\
144.79\end{array}$ & $\begin{array}{l}162.50 \pm \\
17.20\end{array}$ & $\begin{array}{l}318.40 \pm \\
34.10\end{array}$ & 300 \\
\hline $\begin{array}{l}\text { Cadmium } \\
\text { (Cd) }\end{array}$ & $4.05 \pm 1.25$ & $25.90 \pm 9.53$ & $1.90 \pm 0.63$ & $18.34 \pm 3.81$ & 3.0 \\
\hline Copper (Cu) & $\begin{array}{l}5449.60 \pm \\
482.27\end{array}$ & $\begin{array}{l}3497.5 \pm \\
436.6\end{array}$ & $\begin{array}{l}2395.10 \pm \\
179.41\end{array}$ & $\begin{array}{l}2028.60 \pm \\
217.60\end{array}$ & 50 \\
\hline \multirow[t]{2}{*}{ Zinc (Zn) } & \multirow{2}{*}{$\begin{array}{l}657.10 \pm \\
67.05\end{array}$} & \multirow{2}{*}{$\begin{array}{l}258.60 \pm \\
24.56\end{array}$} & $77.40 \pm$ & $63.90 \pm$ & \multirow[t]{2}{*}{200} \\
\hline & & & 9.31 & 26.20 & \\
\hline Arsenic (As) & $10.86 \pm 1.17$ & $9.89 \pm 3.17$ & $1.80 \pm 0.736$ & $0.75 \pm 0.23$ & - \\
\hline $\begin{array}{l}\text { Mercury } \\
(\mathrm{Hg})\end{array}$ & $0.06 \pm 0.002$ & $0.056 \pm 0.022$ & $0.05 \pm 0.001$ & $0.041 \pm 0.018$ & - \\
\hline Nickel (Ni) & $36.01 \pm 4.46$ & $25.2 \pm 6.71$ & $23.92 \pm 6.84$ & $21.3 \pm 4.79$ & - \\
\hline $\begin{array}{l}\text { Chromium } \\
\text { (Cr) }\end{array}$ & $0.428 \pm 0.126$ & $0.329 \pm 0.091$ & $0.245 \pm 0.076$ & $0.129 \pm 0.031$ & 400 \\
\hline
\end{tabular}

Table 6: Hazardous Metal(loid)s Contamination in soil (Site 4 ,Mean \pm SD) 


\begin{tabular}{|c|c|c|c|c|c|}
\hline \multirow[t]{2}{*}{ Parameter } & \multicolumn{2}{|l|}{ Depth $0-15 \mathrm{~cm}$} & \multicolumn{2}{|c|}{ Depth $15-45 \mathrm{~cm}$} & \multirow{2}{*}{$\begin{array}{l}\text { USEPA } \\
\text { Standard } \\
(\mathrm{mg} / \mathrm{kg})\end{array}$} \\
\hline & $\begin{array}{l}\text { Pre-monsoon } \\
\text { in } \mathrm{mg} / \mathrm{kg}\end{array}$ & $\begin{array}{l}\text { Post- } \\
\text { monsoon } \\
\text { in } \mathrm{mg} / \mathrm{kg}\end{array}$ & $\begin{array}{l}\text { Pre-monsoon } \\
\text { in } \mathrm{mg} / \mathrm{kg}\end{array}$ & $\begin{array}{l}\text { Post-monsoon } \\
\text { in } \mathrm{mg} / \mathrm{kg}\end{array}$ & \\
\hline Lead (Pb) & $\begin{array}{l}1834.60 \pm \\
192.50\end{array}$ & $\begin{array}{l}2042.27 \pm \\
206.80\end{array}$ & $\begin{array}{l}297.00 \pm \\
31.30\end{array}$ & $\begin{array}{l}419.70 \pm \\
44.70\end{array}$ & 300 \\
\hline $\begin{array}{l}\text { Cadmium } \\
\text { (Cd) }\end{array}$ & $5.98 \pm 1.48$ & $20.93 \pm 3.37$ & $1.90 \pm 0.34$ & $12.40 \pm 2.14$ & 3.0 \\
\hline Copper (Cu) & $\begin{array}{l}6967.30 \pm \\
711.70\end{array}$ & $\begin{array}{l}4471.54 \pm \\
453.10\end{array}$ & $\begin{array}{l}1517.30 \pm \\
173.40\end{array}$ & $\begin{array}{l}3928.60 \pm \\
356.42\end{array}$ & 50 \\
\hline Zinc (Zn) & $\begin{array}{l}526.20 \pm \\
122.3\end{array}$ & $\begin{array}{l}103.40 \pm \\
19.68\end{array}$ & $99.50 \pm 23.65$ & $79.00 \pm 23.77$ & 200 \\
\hline Arsenic (As) & $17.80 \pm 3.33$ & $15.38 \pm 7.27$ & $10.50 \pm 2.92$ & $8.87 \pm 1.87$ & - \\
\hline $\begin{array}{l}\text { Mercury } \\
(\mathrm{Hg})\end{array}$ & $0.052 \pm 0.014$ & $0.063 \pm 0.018$ & $0.039 \pm 0.176$ & $0.038 \pm 0.027$ & - \\
\hline Nickel (Ni) & $49.30 \pm 19.5$ & $37.00 \pm 15.8$ & $32.60 \pm 14.70$ & $31.70 \pm 8.72$ & - \\
\hline $\begin{array}{l}\text { Chromium } \\
\text { (Cr) }\end{array}$ & $0.701 \pm 0.312$ & $0.528 \pm 0.216$ & $0.423 \pm 0.193$ & $0.392 \pm 0.091$ & 400 \\
\hline
\end{tabular}

Table 7: Hazardous Metal(loid)s in soil (control site , Mean \pm SD) 


\begin{tabular}{|c|c|c|c|c|c|}
\hline \multirow[t]{3}{*}{$\begin{array}{l}\text { Heavy } \\
\text { metals }\end{array}$} & \multicolumn{4}{|c|}{$\begin{array}{l}\text { Heavy metal concentration in Nishapur (Control) at Sangrampur } \\
(\mathrm{mg} / \mathrm{kg})\end{array}$} & \multirow{3}{*}{$\begin{array}{l}\text { USEPA } \\
\text { Standard } \\
(\mathrm{mg} / \mathrm{kg})\end{array}$} \\
\hline & \multicolumn{2}{|l|}{ Depth $0-15 \mathrm{~cm}$} & \multicolumn{2}{|c|}{ Depth $15-45 \mathrm{~cm}$} & \\
\hline & Pre-monsoon & Post-monsoon & Pre-monsoon & Post-monsoon & \\
\hline Lead (Pb) & $17.50 \pm 0.87$ & $17.4 \pm 0.75$ & $16.67 \pm 1.002$ & $16.3 \pm 0.81$ & 300 \\
\hline $\begin{array}{l}\text { Cadmium } \\
\text { (Cd) }\end{array}$ & $1.67 \pm 0.79$ & $1.81 \pm 0.86$ & $1.66 \pm 0.16$ & $1.65 \pm 0.035$ & 3.0 \\
\hline Copper (Cu) & $32.27 \pm 0.72$ & $31.9 \pm 0.70$ & $27.55 \pm 1.13$ & $26.3 \pm 1.08$ & 50 \\
\hline Zinc (Zn) & $61.27 \pm 1.15$ & $60.1 \pm 1.05$ & $57.48 \pm 0.65$ & $58.0 \pm 0.54$ & 200 \\
\hline Arsenic (As) & $5.13 \pm 0.61$ & $4.76 \pm 1.04$ & $3.14 \pm 0.29$ & $3.31 \pm 0.25$ & - \\
\hline Mercury (Hg) & $0.038 \pm 0.002$ & $0.039 \pm 0.006$ & $0.017 \pm 0.001$ & $0.016 \pm 0.001$ & - \\
\hline Nickel (Ni) & $18.63 \pm 0.67$ & $18.30 \pm 0.90$ & $17.18 \pm 0.35$ & $16.81 \pm 0.53$ & - \\
\hline $\begin{array}{l}\text { Chromium } \\
\text { (Cr) }\end{array}$ & $0.231 \pm 0.154$ & $0.125 \pm 0.063$ & $0.211 \pm 0.117$ & $0.105 \pm 0.088$ & 400 \\
\hline
\end{tabular}

Table 8: Global scenario of Environmental Contamination from different E-waste Informal Sites 


\begin{tabular}{|c|c|c|c|c|c|}
\hline Country & $\begin{array}{l}\text { Environmental } \\
\text { issue/concern }\end{array}$ & $\begin{array}{l}\text { Nature of } \\
\text { handling/disposal }\end{array}$ & $\begin{array}{l}\text { Nature of } \\
\text { contaminants }\end{array}$ & $\begin{array}{l}\text { Exposure } \\
\text { levels }\end{array}$ & References \\
\hline $\begin{array}{l}\text { China } \\
\text { and } \\
\text { Hong } \\
\text { Kong }\end{array}$ & $\begin{array}{l}\text { Atmospheric } \\
\text { pollution }\end{array}$ & Recycling Centre & Upto 2765 pg/m 3 & PBDEs & $\begin{array}{l}\text { Li et al. } \\
\text { (2006) }\end{array}$ \\
\hline China & $\begin{array}{l}\text { Soil-plant - } \\
\text { crop }\end{array}$ & Recycling site & NA & $\begin{array}{l}\text { PBDEs, PCBs } \\
\text { and PCDD/Fs }\end{array}$ & $\begin{array}{l}\text { Liu et al. } \\
\text { (2008) }\end{array}$ \\
\hline China & $\begin{array}{l}\text { Soil-Plant- } \\
\text { Crop (Human } \\
\text { uptake via } \\
\text { rice) }\end{array}$ & $\begin{array}{l}\text { Agricultural field } \\
\text { adjacent to } \\
\text { recycling site }\end{array}$ & $\begin{array}{l}3.7 / 0.7 \\
\mu \mathrm{g} / \mathrm{day} / \mathrm{kg} \text { (dry } \\
\text { wt.) }\end{array}$ & $\begin{array}{l}\text { Heavy metal } \\
\mathrm{Pb} \& \mathrm{Cd}\end{array}$ & $\begin{array}{l}\text { Fu et al. } \\
\text { (2008) }\end{array}$ \\
\hline China & $\begin{array}{l}\text { Human (child } \\
\text { blood sample) }\end{array}$ & $\begin{array}{l}\text { Exposure to } \\
\text { worker in } \\
\text { recycling site }\end{array}$ & $10 \mu \mathrm{g} / \mathrm{dl}$ & $\mathrm{Cd}$ & $\begin{array}{l}\text { Zheng et } \\
\text { al. (2008) }\end{array}$ \\
\hline India & $\begin{array}{l}\text { Soil - } \\
\text { (ground) } \\
\text { Water } \\
\text { environment }\end{array}$ & Recycling site & NA & $\begin{array}{l}\text { Heavy metals } \\
(\mathrm{Cu}, \mathrm{Al}, \mathrm{Pb} \text {, } \\
\mathrm{Zn}, \mathrm{Ni}, \mathrm{Mn} \text { and } \\
\mathrm{Cd})\end{array}$ & $\begin{array}{l}\text { Dwivedy et } \\
\text { al. (2015) } \\
\text { Gidarakos } \\
\text { et al. } \\
(2012)\end{array}$ \\
\hline India & $\begin{array}{l}\text { Soil- (surface) } \\
\text { Water } \\
\text { environment }\end{array}$ & $\begin{array}{l}\text { Recycling site ( } \\
\text { outskirts of } \\
\text { megacities ) }\end{array}$ & $\begin{array}{l}\mathrm{Pb}(637.8 \pm 63.70) \\
\mathrm{Cu}(2576 \pm 235.80) \\
\mathrm{As}(14.69 \pm 4.08) \\
\mathrm{Hg}(0.05 \pm 0.01)\end{array}$ & $\begin{array}{l}\text { Heavy metals } \\
(\mathrm{Cd}, \mathrm{Se}, \mathrm{Zn} \\
\text {, } \mathrm{Pb}, \mathrm{Ni}, \mathrm{As}, \mathrm{Cu}, \\
\mathrm{Cr})\end{array}$ & $\begin{array}{l}\text { Dasgupta } \\
\text { et al. } \\
(2017)\end{array}$ \\
\hline Vietnam & $\begin{array}{l}\text { Human (THs } \\
\text { Thyroid } \\
\text { hormones) }\end{array}$ & Recycling site & NA & $\begin{array}{l}\text { PCBs, } \\
\text { hydroxylated } \\
\text { PCBs (OH- } \\
\text { PCBs), PBDEs, }\end{array}$ & $\begin{array}{l}\text { Hischier et } \\
\text { al. (2005) } \\
\\
\text { Eguchi et } \\
\text { al. (2015) }\end{array}$ \\
\hline Ghana & $\begin{array}{l}\text { Atmospheric } \\
\text { pollution }\end{array}$ & $\begin{array}{l}\text { Recycling and } \\
\text { disposal site }\end{array}$ & $\begin{array}{l}\mathrm{Al}(6.5) \mathrm{Cu}(1.2) \\
\mathrm{Fe}(8.9) \mathrm{Pb}(0.98 \\
\text { ) mg. m-3, }\end{array}$ & $\begin{array}{l}\text { Heavy metals } \\
(\mathrm{Al}, \mathrm{Cu}, \mathrm{Fe} \text {, } \\
\mathrm{Pb})\end{array}$ & $\begin{array}{l}\text { Khetriwal } \\
\text { et al. } \\
(2009) \\
\text { Caravanos } \\
\text { et al. } \\
(2011)\end{array}$ \\
\hline Nigeria & $\begin{array}{l}\text { Soil } \\
\text { environment }\end{array}$ & Recycling site & $\begin{array}{l}\mathrm{Cu} \text { (upto7106) } \\
\mathrm{Pb}(9623), \mathrm{Zn}^{-1} \\
(8178) \mathrm{mg} \mathrm{kg}^{-1}\end{array}$ & $\begin{array}{l}\text { Heavy metals } \\
(\mathrm{Cu}>\mathrm{Pb}>\mathrm{Zn} \\
>\mathrm{Mn}>\mathrm{Ni}>\mathrm{Sb} \\
>\mathrm{Cr}>\mathrm{Cd})\end{array}$ & $\begin{array}{l}\text { Oluyemi et } \\
\text { al. (2008) } \\
\text { Isimekhai } \\
\text { et al. } \\
\text { (2017) }\end{array}$ \\
\hline
\end{tabular}




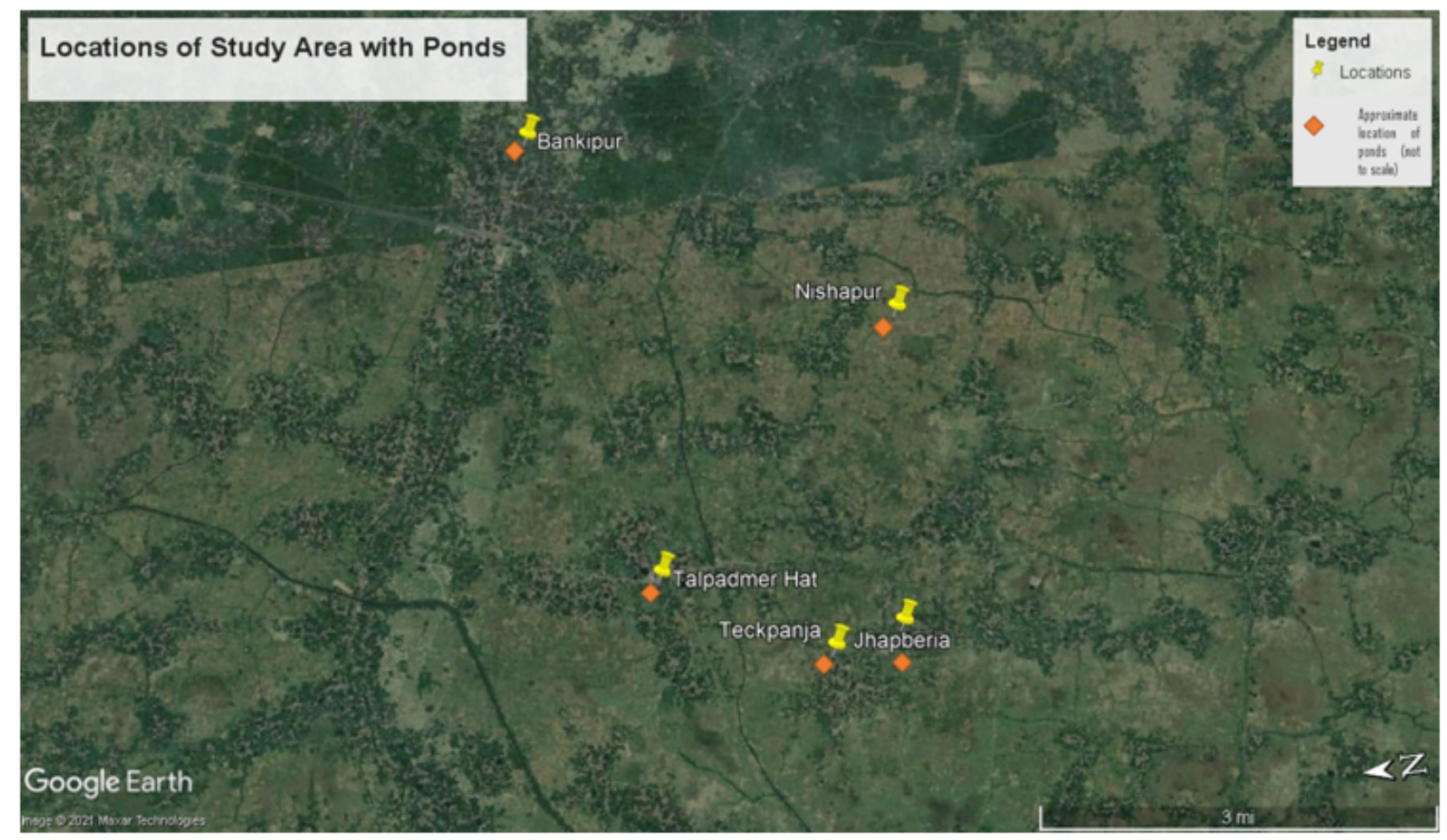

Site 1 (Teckpanja): $\quad 22^{\circ} 12^{\prime} 33.0^{\prime \prime} \mathrm{N}$ and $88^{\circ} 18^{\prime} 57.5^{\prime \prime} \mathrm{E}$,

Site 2 (Bankipur): $\quad 22^{\circ} 14^{\prime} 07.6^{\prime \prime} \mathrm{N}$ and $88^{\circ} 22^{\prime}$ 57.1" $\mathrm{E}$

Site 3(TalpadmerHat): $22^{\circ} 13^{\prime} 37.7^{\prime \prime} \mathrm{N}$ and $8^{\circ}{ }^{\circ} 19^{\prime} 38.8^{\prime \prime} \mathrm{E}$

Site 4( Jhapberia): $\quad 22^{\circ} 12^{\prime} 04.7^{\prime \prime} \mathrm{N}$ and $88^{\circ} 19^{\prime} 03.9^{\prime \prime} \mathrm{E}$

Site 5 (Nishapur): $\quad 22^{\circ} 11^{\prime} 49^{\prime \prime} \mathrm{N}$ and $88^{\circ} 21^{\prime} 18.9^{\prime \prime} \mathrm{E}$

Figure 1

Study area - Sangrampur, West Bengal. 
b)

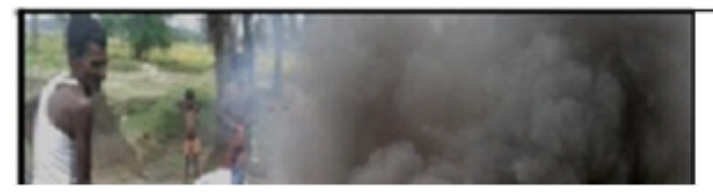

\section{E-Waste Components (\%)}

Metal (non-ferrous)

20

\section{Figure 2}

a) Microscale open burning site (Teckpanja - Site 1); b) Common constituent materials that end up as ewaste around the study site.

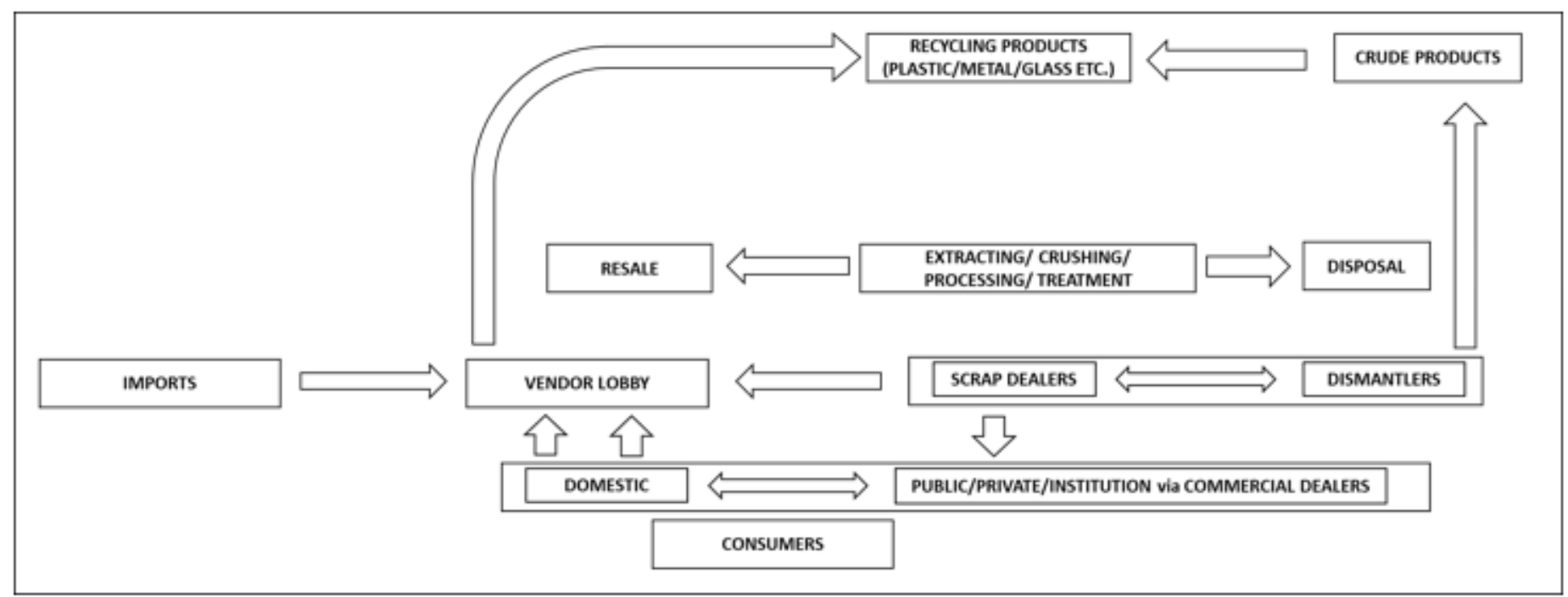

\section{Figure 3}

Flow diagram of e-waste trade chain in India: from market to end disposal perspective. 


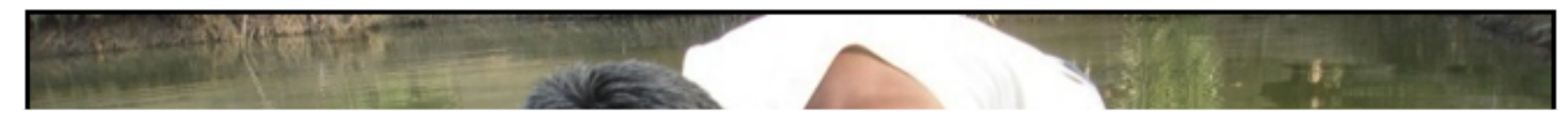

Figure 4

Handlers washing metal(loid)s recovered from processed e-wastes in local pond waters. 


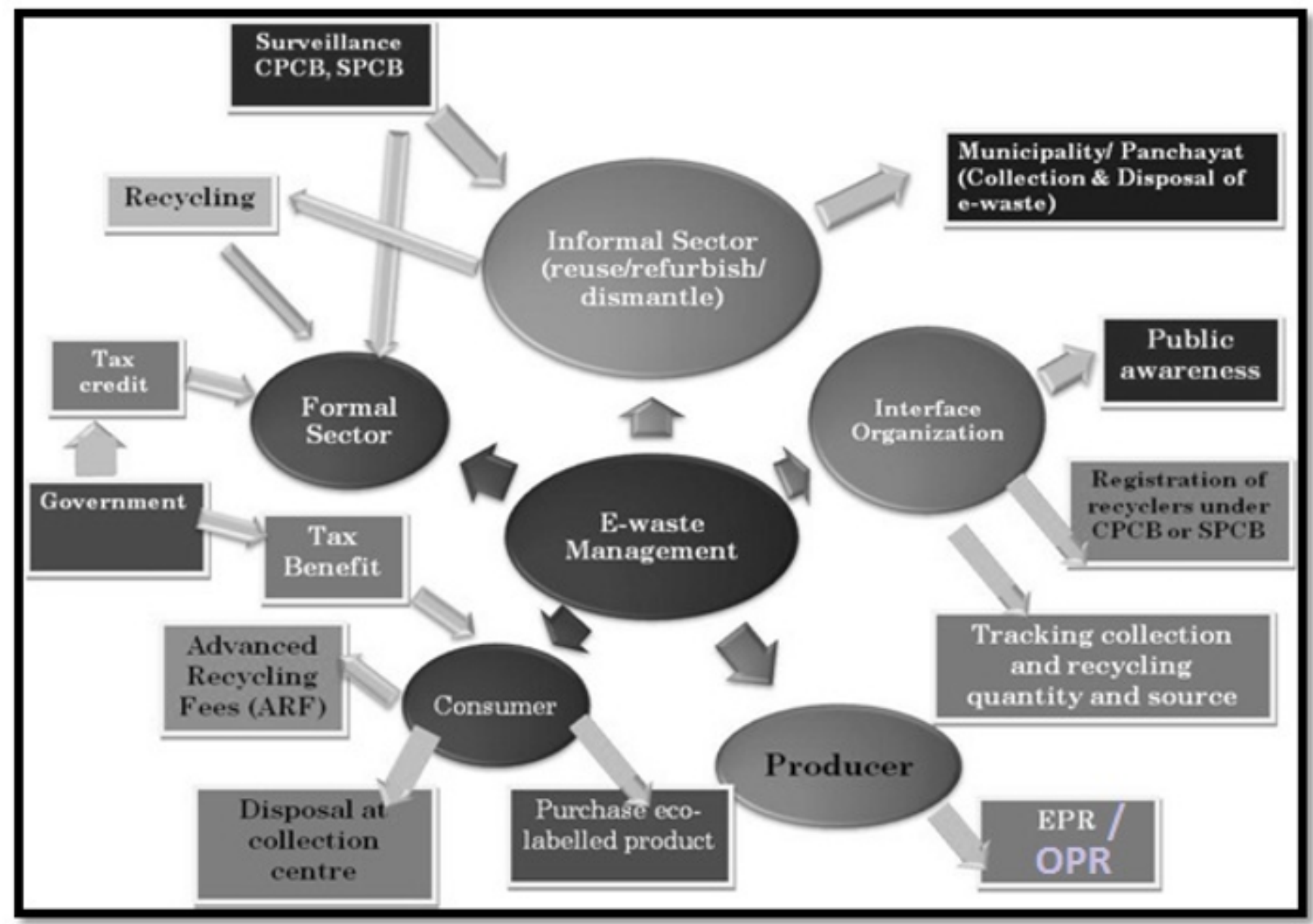

Figure 5

Schematic diagram for proposed 'Skilful E-waste Management Model' to improve e-waste management practices in Indian subcontinent - a vision for moving from informal to formal sectors. 